\title{
Profitable Nonprofits? Reward-Based Crowdfunding in the Czech Republic
}

Lucia Makýšová, Gabriela Vaceková

\begin{abstract}
This paper deals with crowdfunding as a new and alternative mechanism of nonprofit funding which has thus far attracted little scholarly attention in the Czech context. It focuses on the factors that affect a campaign's overfunding rate and determines whether these factors are consistent among different forms of project creators. A comprehensive analysis of reward-based crowdfunding in the Czech Republic was conducted based on the data from 617 projects using the Czech crowdfunding platform Hithit that were categorized according to the status of the project creator. Using binary logistic regression, a statistic estimation on an overall sample and on a sample of purely nonprofit projects was executed in order to observe if the outcomes differ. The key empirical finding is that NGOs tend to raise fewer additional funds than other forms of project creators. Except for certain specific factors, the effects of the examined factors were consistent across all samples. This new and innovative approach to resource insufficiency by using alternative funding sources presents an important and unexplored research gap in the (post-) transitive context of nonprofit sector studies, enabling a view of policy implications for Czech NGOs.
\end{abstract}

\section{Keywords:}

NGO; Crowdfunding; Overfunding; Resource Insufficiency; Hithit; Czech Republic

\section{Introduction}

The present study is motivated by the recent and ongoing changes in the position and functioning of nonprofit organizations lacking sufficient funding sources. These changes require a corresponding scientific approach and have policy implications for enabling appropriate solutions. The nonprofit sector is a major player in politics and economics all over the world. The role of nonprofit organizations in (post-) 
transitional countries is certainly considerable and worthy of study. Salamon and Sokolowski (2016) make clear that the third sector is far from following the same patterns in different parts of Europe. "Important though these aggregate features of the third sector are, however, they can be misleading. ... Behind the averages often lie some significant cross-national and regional variations. And that is certainly true of the European third sector" (ibid., 15). To make sense of these variations, it is useful to examine them at the regional level. Nonprofit funding and resource insufficiency are among the most popular topics related to the public-policy issues in Central and Eastern Europe (CEE). This paper deals with the phenomenon of crowdfunding, which has thus far attracted little scholarly attention in the Czech context. The emerging argument supporting the importance of this research issue is that the societal determinants of the nonprofit sector in CEE, at least in the short and mid-term, are mainly related to supply-side rather than demand-side determinants (cf. Valentinov and Vaceková 2015), with the supply-side factors including public funding, public regulation, and the legal environment of the nonprofit sector.

\subsection{The state of the art}

Recently, there has been a considerable surge of interest throughout the world in the broad range of organizations that operate outside the market and the state (Salamon et al. 1999). Known variously as the nonprofit, nongovernmental, voluntary, civilsociety, third, or independent sector ${ }^{1}$ (Salamon et al. 2000), organizations that can demonstrate that their activities generate a public benefit or common social good exist in some form of special incorporation or registration in every country (Casey 2016). In recent decades, the activity and influence of nonprofit organizations have grown exponentially (Casey 2016; CIVICUS 2013; Colás 2002; McCarthy et al. 1992; Salamon 2010; Salamon and Sokolowski 2010). Salamon (1994) wrote about a global "associational revolution" focusing primarily on the growth of nonprofit organizations and their increasing role in service delivery. Nonprofit organizations have become central to policy-making, the promotion of civic action, and the delivery of new quasi-public services, as well. In addition to being more numerous, modern nonprofit organizations (perhaps better described as late-modern or even post-modern) are markedly more secular and nonpartisan in their affiliations, more universalist in their service-delivery and policy-making aspirations, and more professionalized and commercialized in their operations than earlier iterations rooted in religious charity, political movements, or grassroots collective and voluntary action (Casey 2015). However, the nonprofit sector of every country is the result of its particular social, economic, and political history (Casey 2016). The origin, function, and mode of operation of the nonprofit sector in each country reflect the unique circumstances of that country (DiMaggio and Anheier 1990; James 1989; Kramer

1 The term nonprofit was chosen as the primary term for use in this paper because it is currently widely recognized as both a concept and descriptor, both in its English form and in its translation into other languages (cf. Casey 2015). 
1981; McCarthy et al. 1992; Pryor 2012; Salamon and Anheier 1997; Salamon and Sokolowski 2010; Skocpol 2011). Salamon and Anheier $(1992,1998)$ wrote of "social origins" and "nonprofit regimes," whereas Anheier et al. (2001) talked about "national scripts." It is necessary to take the (post-) transitional context into account when focusing on the burning issue of resource insufficiency.

Resource insufficiency is one of the inherent limitations of the voluntary sector, reflecting the difficulties with generating resources on a scale that is both adequate and sufficiently reliable to cope with the range of human problems it seeks to address (Salamon 1987; Billis and Glennerster 1998; Kramer 1981; Lewis 1998; Ostrander 1989; Grønbjerg 1994; Fowler 1995; Murray Svidroňová et al. 2016). This is, to a considerable extent, a product of the "free rider" problem inherent in the production of collective goods. Since everybody benefits from a society in which those in need are cared for even if they have not contributed to paying for the care, there is an incentive for each person to let their neighbor bear most of the cost. As long as reliance is placed solely on a system of voluntary contributions, therefore, it is likely that the resources made available will be less than those that the society actually considers optimal. Furthermore, because of the twists of economic fortune, benevolent individuals may find themselves least able to help those in need when the need is greatest. In addition, the usually available resources are frequently not available where the problems are most severe. Therefore, nonprofit organizations have serious challenges in generating a reliable stream of resources to address community needs.

NGOs lacking funds (not only) during times of austerity (cf. Hrůza 2013; Hrůza and Valouch 2014) may focus on alternative funding sources, e.g. crowdfunding. Crowdfunding has its roots in two concepts: in crowdsourcing (Kleeman et al. 2008, Belleflamme et al. 2010) and in microfinancing (Morduch 1999). The term "crowdfunding" was first introduced by Michael Sullivan in 2006. His concept of financing was "based on reciprocity, transparency, shared interests and, above all, funding from the crowd" (Castrataro 2011). Since then, several scholars have tried to capture the specific characteristics of crowdfunding. Belleflamme et al. 2014 used Kleeman et al.'s definition (2008) of crowdsourcing and extended it to define crowdfunding as a "an open call, essentially through the internet, for the provision of financial resources either in form of a donation or in exchange for some form of reward and/or voting rights, in order to support initiatives for specific purposes" (Belleflamme et al. 2014, 588). Ordanini et al. (2011) considered the internet to be a key element of crowdfunding. Joenssen et al. (2014), however, argued that the basis of crowdfunding is not determined by the launch of crowdfunding campaigns on the internet and suggested that crowdfunding is "a process where commercial or non-commercial projects are initiated in a public announcement by organizations or individuals to receive funding, assess the market potential, and build customer relationships. Pledgers may then contribute individual amounts of monetary or non-monetary resources, during a specified timeframe, using offline or online cam- 
paign platforms that utilize different pay-out schemes, in exchange for a product specific or unspecific, material or immaterial reward" (ibid., 6).

Mollick (2014) argued that the problem with the definition by Belleflamme et al. (2014) lies in the fact that it may potentially omit certain fields that are covered by crowdfunding, for example peer-to-peer or equity lending. At the same time, he added that it is impossible to capture all aspects of crowdfunding. Hence, Mollick defines crowdfunding as "the efforts by entrepreneurial individuals and groups - cultural, social, and for-profit - to fund their ventures by drawing on relatively small contributions from a relatively large number of individuals using the internet, without standard financial intermediaries" (ibid., 2). As Younkin and Kashkooli (2016) suggested, using crowdsourcing to obtain financial assets can solve two problems. First, collecting money through a platform can help with coordinating contributions from the group around the fund seekers. Second, those for whom access to traditional means of obtaining assets has been denied can use crowdfunding to raise the required finances. Moreover, collecting money via a crowdfunding platform enables finance seekers to gain access to new networks. Liu (2015) highlights the point that crowdfunding makes financial assets more accessible, and the distribution of money is more democratic and supports community development. Based on these facts, this paper works with the definition of crowdfunding as an online process in which commercial or non-commercial projects are publicly initiated through a crowdfunding platform by individuals or organizations that seek to raise funds in the form of small investments from a "crowd" of backers who provide their free assets, either in the form of a donation or in exchange for a monetary or non-monetary reward.

\subsection{Objectives and research questions}

We study the relationship between funds raised in crowdfunding campaigns launched on the crowdfunding platform Hithit and selected factors affecting their overfunding, paying special attention to: (1) the whole sample of projects, and (2) the projects created solely by NGOs. The following research questions were set:

RQ1. Which factors affect the level of a campaign's overfunding?

RQ2. Do these factors differ among various forms of project creators? If so, how?

This paper seeks to answer these questions and to establish a possible basis for their solutions. The paper's objective is to introduce the new and innovative approach of crowdsourcing into research on resource insufficiency in the (post-) transitional context of the Czech nonprofit sector. By analyzing the factors affecting campaign overfunding in crowdsourcing, the paper provides insight into the differences that can occur when raising funds through crowdfunding depending on whether the project creator is an NGO or another entity. Hence, the paper widely contributes to public-policy debates: as an institutional and legal phenomenon, 
crowdfunding may be seen in the context of the ongoing evolutionary trends of the Czech welfare state (Soukopová and Klimovský 2016). Horák et al. (2013) argue that the nature of the public-private mix of social-service delivery is being affected by the processes of the centralization of decision-making, the marketization and contractualization of service delivery, the growing use of new-public-management methods, organizational innovation (Nemec et al. 2016), and the increasing networking between state and nonstate organizations (Vaceková et al. 2017). At the bottom, these trends reflect the increasing involvement of the nonprofit sector in service-delivery processes, as well as its closer entanglement and coordination with the public and private for-profit sectors (Bode and Brandsen 2014). In the Czech institutional context (cf. Nemec et al. 2014), it is plausible to conjecture that crowdfunding constitutes a part of the evolutionary dynamics of the welfare state (Vaceková et al. 2017).

\section{Material and methods}

Most research focuses on analyzing data from Kickstarter (Kuppuswamy and Bayus 2013; Belleflamme et al. 2013; Mollick 2014), Indiegogo (Cordova et al. 2015), and Sellaband (Agrawal et al. 2011). For a new viewpoint, the data used in this paper was collected from the crowdfunding platform Hithit, which is the largest crowdfunding platform in the Czech Republic.

\subsection{Data and sources}

The data used in the analysis was manually collated from the reward-based crowdfunding platform Hithit and contains information on all successfully completed projects. Hithit operates on an all-or-nothing (AON) financial scheme. Projects are, therefore, only considered successful projects if they received at least $100 \%$ of the requested amount. From December 2012, when the first successful project was launched, up to the end of January 2017, 617 projects were successfully financially supported via Hithit, raising a total of 78.7 million Czech crowns. Most of the dataset was extracted directly from the platform website in January and February 2017. Data from all 617 successfully funded projects was extracted. Five of these were later excluded, because the project creator was a foreign organization, and it was not possible to collect all the information required for the analysis. Dividing the data into an overall sample and a sample consisting solely of projects created by NGOs made it possible to compare the effects of selected factors.

\subsection{The empirical model}

The collected data used in the research is cross-sectional and lacks any time dimension. As a dependent variable, the overfunding rate was chosen. The value was counted as the proportion between the amount of money raised and the required 
amount. Because of the lack of information on unsuccessful projects, the overfunding rate ranges between 1.00 and higher. The explanatory variable used in the analysis can be divided according to the source where the data was collected. The following data was obtained from each project profile:

- Requested represents the volume of funds that the project creator intended to raise. All projects are counted in Czech crowns. If the project raised funds in Euros, the platform automatically converted the amount into Czech currency. In the estimation, the logarithmic form of the variable is applied;

- Funders are the number of people who financially contributed to each project;

- ContribFunder indicates the mean amount of money contributed by each funder. In the estimations, the logarithmic form is used;

- Interaction of the requested amount and mean contribution per funder is introduced in order to observe whether the trend for mean contribution per funder changes with increasing requested amounts. Both variables are used in the interaction in logarithmic form;

- Updates stand for the sum of updates that the fundraiser posted during the campaign in the project profile;

- Comments are the number of comments that the project creator and everyone interested in the project wrote in the project profile during the campaign;

- Video is a variable used in the form of a dummy variable. 1 stands for projects that uploaded a video on the project profile, 0 if otherwise;

- Rewards consists of information about the number of rewards offered by the fundraiser as compensation for the funder's contribution;

- NGOnotNGO represents a dummy variable. 1 stands for a project created by a NGO, 0 if otherwise. The information about the type of project creator was found either in the project profile or in the links uploaded to the profile, where further information about the project can be obtained. Subsequently, if the project creator was an organization, a specific register was used to check if the organization was an NGO. For Czech organizations, the database of the Czech Statistical Office was used; for Slovak organizations, the information was found in the database of the Statistical Office of the Slovak Republic;

- Category is a dummy variable that divides projects according to the project topic. On Hithit, it is possible to launch projects related to at least one of these fifteen categories: Arts, Community, Dance, Design, Education, Fashion, Food, Games, Literature, Movie, Music, Photos, Sports, Technology, and Theater. However, not every category contains a large number of samples. Therefore, some categories were merged, and the final number of categories was reduced to ten: Arts; Community; Design \& Technology; Education; Literature \& Photos; Movie; Music; Others; Sports; and Theater \& Dance. 
For projects created by NGOs, further data was collected:

- Existmonths is the number of months that the NGO existed before the campaign was launched. The number of existing months for each organization was calculated as the difference between the date when the NGO was registered in a specific register and the date when the campaign was launched. The data was collected from the Czech Statistical Office and from the Statistical Office of the Slovak Republic;

- Munpop represents the population of a municipality where the NGO is localized. The data was collected from the Czech Statistical Office and from the Statistical Office of the Slovak Republic.

Appendix 1 depicts the values of the correlations between each variable for each sample. When comparing the results with all samples, the correlation between each two variables reached weak or mediate values of correlation. To see the impact of the chosen independent variables on a campaign's overfunding, binary logistic regression, as the standard estimation used in literature (e.g. Mollick 2014; Joenssen et al. 2014; Zvilichovsky et al. 2015), is applied. This model has been used by researchers to test factors for crowdfunding success and to estimate the data from successful and unsuccessful projects. However, the data used in this paper consists solely of information on the successful projects. For that reason, the overfunding rate was chosen for the estimate.

Binomial logistic regression estimates the dependent variable in forms of 0 and 1. For that purpose, the projects were sorted into funded and overfunded projects. The threshold used for the selection was set at a $5 \%$ level, dividing projects as follows:

\section{$y_{i}=\left\{\begin{array}{l}1 \text { if overfunding reached at least } 1.05 \text { of requested amount } \\ 0 \text { if otherwise. }\end{array}\right.$}

With the selected variables, the final version of the binary logistics regression (Hosmer and Lemeshow 2000) is as follows:

$P(y=1 \mid x)=\frac{e^{g(x)}}{1+e^{g(x)}}$,

with $\mathrm{g}(\mathrm{x})$ for the overall sample:

$$
\begin{aligned}
& \boldsymbol{g}(x)=\beta_{0}+\beta_{1} \log \text { Requested }+\beta_{2} \text { Funders }+\beta_{3} \text { log ContribFunder } \\
& +\beta_{4}(\text { logRequested } * \text { logContribFunder })+\beta_{5} \text { Updates }+\beta_{6} \text { Comments }+\beta_{7} \text { Video } \\
& +\beta_{8} \text { Rewards }+\beta_{9} \text { NGOnotNGO }+\sum_{i=1}^{N}\left(\beta_{9+i} \text { Category }\right)+\varepsilon,
\end{aligned}
$$


and with $\mathrm{g}(\mathrm{x})$ for the NGO sample:

$$
\begin{aligned}
& \boldsymbol{g}(\boldsymbol{x})=\beta_{0}+\beta_{1} \log \text { Requested }+\beta_{2} \text { Funders }+\beta_{3} \text { logContribFunder } \\
& +\beta_{4}(\text { logRequested } * \text { logContribFunder })+\beta_{5} \text { Updates }+\beta_{6} \text { Comments }+\beta_{7} \text { Video } \\
& +\beta_{8} \text { Rewards }+\beta_{9} \text { Existmonths }+\beta_{10} \text { Munpop }+\sum_{i=1}^{N}\left(\beta_{11+i} \text { Category }\right)+\varepsilon .
\end{aligned}
$$

The explanatory variables logRequested, Funders, logContribFunder and $\operatorname{logRequested}{ }^{*} \log$ ContribFunder were chosen as the variables of interest. There is also a control for the project characteristics, as Updates, Comments, Video, and Rewards. In the NGO sample, the control variables are extended by Existmonths and Muпрор. Furthermore, there are the estimation controls for environmental characteristics, such as the type of project owner (NGOnotNGO) and Category.

\section{Results}

Before providing an overall description of the data-analysis outcomes and the results obtained, the paper offers the following highlights. Across all the models, the funders were identified to have a positive effect on overfunding, whereas the higher total requested amount negatively influences the collection of extra funds. The funders contribute more per person when the requested amount is set at a higher level. Certain characteristics of the projects were not proven to be significant across all samples: video, number of updates and number of rewards. The estimations showed that overfunding is not favorable for projects created by NGOs. The estimation that focused solely on NGOs consistently found that the length of organization existence was insignificant in raising extra funds.

\subsection{Descriptive statistics}

The summary statistics are depicted in Appendix 2. The overall dataset contains 612 projects, of which 212 were created by NGOs and 400 were established by a different creator (individual, business company, or other entity). In the overall data, the projects set goals at an average level of 106,000 Czech crowns but raised funds 1.17 times higher. The highest overfunding was reached by a project that raised funds more than six times higher than its stated goal. On average, each project was financially supported by 158 funders, each contributing approximately 1,019 Czech crowns. Project creators uploaded around 3.6 updates during the campaign and offered around 15 distinct types of rewards as compensation for financial support. Backers and other people interested in the projects left an average of two comments total per project.

In the NGO-only data, on average, projects created by NGOs raised approximately 17,800 more crowns than the overall project average. However, the raised 
amount relates to the requested amount, which on average was set at a higher value for NGO projects than for the projects overall. Project overfunding reached on average $11 \%$ of the goal and was 6 percentage points lower than the mean overfunding level calculated for all projects. On average, 166 funders financially contributed per project, with a contribution of 1,031 Czech crowns. All the indicators show higher values when only the projects created by NGOs are counted. Similar to the projects overall, NGO project creators made an average 3-4 updates per campaign. A slight difference can be observed in the behavior of people interested in the project, who on average communicated through comments less often when the project creator was an NGO rather than when all the projects were counted. On average, more rewards were offered by NGO project creators.

The age of each organization before the project was launched significantly differs in the sample. The youngest organization came into existence only a few days before launching its campaign on Hithit; the oldest had been operating on the market for almost 38 years. The mean age of an organization before the project was launched was estimated at 115 months or 9.6 years. Fifty-five percent of the projects were launched by organizations located in Prague. According to the Czech Statistical Office, the population of the capital is estimated at 1.26 million inhabitants. In contrast, one NGO from the sample was operating in a municipality with a population of 106 inhabitants.

\subsection{Explanation of project overfunding}

Binary logistic regression was used to isolate relevant results explaining project overfunding. The odds ratios for both data samples are depicted in Appendix 3. The odds ratio represents the proportion of two probabilities; in this case, the probability of being overfunded and being just funded. The first model considered the data from all the projects; the remaining models used just the sample of the NGO projects.

A) In addressing RQ1, this paper adds to the clarification of factors affecting the level of a campaign's overfunding rate.

In Model 1, which estimated the original sample, two factors were associated with a positive impact on overfunding: funders and mean contribution per funder. When only an odd ratio for the mean contribution per funder is considered, it indicates a negative effect. However, the variable is also included in the interaction with the requested amount; therefore, both coefficients are counted together, showing the positive effect on campaign overfunding. The statistically significant interaction provides information about the increasing mean contribution per funder with respect to the higher requested amount. Moreover, educationally oriented projects appeared to have higher odds of being overfunded in respect to music projects. On the other hand, an increase in the requested amount and comments are found to be associated with a negative impact on overfunding. The outcomes also imply lower 
odds of receiving extra funds if the project creator is an NGO and if a project is related to literature or photography.

The variables related to characteristics such as number of updates, uploading of video to the project profile, and number of rewards were not proven to affect project overfunding.

B) In addressing RQ2, this paper contributes to the scientific discussion of differences among various forms of project creators regarding the project success. In explaining these differences, we focus on outcomes resulting from the sample of purely nonprofit projects as compared to the original sample.

Models 2 and 3 estimated the sample of all projects created by NGOs. The model in which the interaction of the requested amount and the mean contribution per funder is included only estimates the number of funders as a statistically significant variable from the variables of interest. Therefore, additional regression was conducted to observe any changes in the significance of the remaining variables (Model 3). By omitting the interaction term, the number of funders remained, positively affecting the odds of being overfunded while the requested amount and the mean contribution per funder appeared to be significant, with the same effect as is estimated in Model 1. The inconsistency in outcomes indicates the difference in funder behaviors. Whereas for the overall sample it was detected that funders reacted to a higher stated goal by increasing their contributions, for the projects created solely by NGOs, the funder behavior remained the same, regardless of any change in the requested amount. The reason for funders tending to change the level of their contribution could be that they are aware that a higher stated goal is related to a higher risk of the project not reaching the goal; therefore, they contribute more. The same assumption cannot be applied to nonprofit projects; to do so requires additional research.

The control variables video and updates were estimated with no effect on overfunding. The results imply that providing additional information did not play a significant role in obtaining extra resources. Similarly, the number of different types of rewards did not have an impact on collecting extra funds. However, the variable provided only quantitative information and lacked any qualitative aspects that might be crucial for funders deciding whether to contribute.

The effect of the number of comments was not proven when only projects of NGOs were considered. Unlike the whole sample, a possible explanation why the overfunding of pure NGOs is not affected may be the different project purpose. NGO projects are related to public benefits; projects created by other entities are usually profit-oriented. For profit-oriented projects, potential backers may consider both positive and negative comments as a benchmark for deciding about their contribution. The model indicates the negative impact of the variable on overfunding. 
Nevertheless, to make a relevant statement concerning the different behavior among various project creators, additional qualitative research should be conducted.

The model related to the overall sample indicated the importance of the type of project creator on the overfunding level. The outcomes suggest that the projects created by NGOs have lower odds of raising extra funds than projects created by another entity. This important result provides a basis for further scientific investigations and opens a space for considering policy implications for nonprofit organizations lacking public funding and being obviously disadvantaged even in crowdfunding activities.

The division of projects according to the project field showed that projects related to education have higher odds of being overfunded. This outcome is consistent for both samples. For projects created by NGOs, the remaining categories do not show any effect on project overfunding.

For projects created by NGOs, two additional factors were included in the estimation. The length of an NGO's existence before the campaign started was estimated as an insignificant factor in affecting overfunding. The outcome indicates that the project has a chance of being overfunded whether the NGO has operated on the market for years or just days before the campaign was launched. Apparently, the transparency and accountability of the organization, as proven by the longer existence of the organization, are irrelevant. This gives a positive signal to newer NGOs that may suffer from a lack of funds from traditional sources to try to use crowdfunding. The effect of municipality population also appeared to be insignificant. Further research should be conducted focusing on the precise location of the backers and the distance between them and the organization.

Since the outcomes of all models show certain control variables to be consistently insignificant, all estimations were subsequently conducted without controlled variables that appeared to be statistically insignificant. For all models, the same variables remained significant at the same level. Appendix 4 summarizes the statistics of how precisely each model could classify each project.

\section{Discussion}

To present the principles, relationships, and generalizations indicated by the paper's findings, the Discussion section is structured as follows: first, we discuss the limitations of the statistic estimations; then, we show how the results and interpretations agree (or contrast) with previously published work and discuss the theoretical implications and practical implications of the paper; and finally, we point out relevant policy implications. 


\subsection{Results limitations}

Regarding the limitations of the provided results, the binary logistic regression correctly classified $72-75 \%$ of all samples. The estimation may be limited by the missing values of unsuccessful projects. The cut-off division between overfunded and funded projects had to be decided arbitrarily; it could be argued that if a project raised only one Czech crown above the stated goal, the project was overfunded. The analysis is deliberately abstract on certain data. First, the effect of a social network was excluded, as the scope and activity on social media can only be monitored during the active campaign. Otherwise, the data could be misleading. However, several analyses show the significant role of social media in project success (e.g. Mollick 2014; Ordanini et al. 2011; and Giudici et al. 2013). Second, instead of using the number of rewards, the quality of rewards could be included. A potential method for evaluating quality would be to split them into a few categories, e.g. whether their value is symbolic, or whether the reward is a presell product. Third, rather than using the size of the population, contributors could be localized and the distance between them and the project creator could be measured. This might help to clarify if the project is supported by people who like the idea of the project or by people who have personal knowledge of the project. Nevertheless, these limitations do not reduce the quality and explanatory power of the results provided; on the contrary, they show the high potential of this research and the directions in which it could move.

\subsection{Result interpretation related to previously published research}

The dichotomy-informed approach to the integrative understanding of the nonprofit sector assumes that the nonprofit sector exists in response to the societal imbalances induced by the well-established for-profit sector (Valentinov 2011; Valentinov et al. 2015). This Anglo-Saxon semantic argument makes perfect sense in the context of the Western world, but it is less applicable to the transitional context of the Central and Eastern European countries, whose institutional structure is still in the process of emerging and forming. The Czech nonprofit sector still faces the challenge of developing its own independent and distinct institutional identity, an integral part of which is financial independence from the state. The attempts of Czech nonprofit organizations to search for alternative funding sources may be vividly illustrated with the crowdfunding phenomenon.

Currently, there is a lack of academic research on campaign overfunding, with no scientific evidence from the (post-) transitional economies of CEE. Overfunding is the situation in which a project collects funds beyond its stated goal. Scholars (cf. Mollick 2014; Belleflamme et al. 2010; Cordova et al. 2015) understand crowdfunding success in financial terms and omit any other goals determined by the project founders. A crowdfunding campaign is considered to be successful when the stated financial goal is reached. The question arises of whether raising extra funds, i.e. 
overfunding, is beneficial for the project creator. Extra funds may create inefficiency. A higher level of overfunding is related to the higher costs of the extra rewards that should be delivered to additional project funders. It can cost more because the project creators may not have the capacity to create more rewards and because they may lack the time to deliver more rewards. It is questionable if the same situation occurs with rewards of a symbolic nature. To observe the effect and whether it varies among the different forms of project creators, additional research should be conducted.

Our findings regarding the level of the requested amount (a negative effect on the overfunding level) are consistent with the findings of Mollick (2014), Koch and Siering (2015), and Cordova et al. (2015). Similarly, the number of funders and the mean contribution per funder (both with a positive effect) support previous research (Cordova et al. 2015). The obtained results prove that the projects created by the NGOs had lower odds of raising extra funds than projects created by another form of creator. This finding is in contrast to the findings of Belleflamme et al. (2013). However, by applying the theory of the two-sided market by Belleflamme et al. (2016), in which potential backers join the market not only for altruistic reasons but also to seek rewards, it is possible that a project created by a profit-seeking entity may introduce a more interesting idea and offer more attractive rewards than a project created by an NGO where the rewards on offer are rather symbolic. The control variables such as video and updates were consistently insignificant among all the samples and models. The results imply that providing additional information does not play a significant role in obtaining extra resources. The outcome corresponds with the findings of Cordova et al. (2015) although it is in contrast to the result obtained by Mollick (2014) and Joenssen et al. (2014). The length of an NGO's existence before the campaign started was estimated as an insignificant factor in overfunding. Comparable results were obtained by Belleflamme et al. (2013) and Navrátil and Vaceková (2015).

\subsection{Policy implications}

The essential lesson from the Czech nonprofit sector seems to be that the sector has tremendous socioeconomic and political potential but is faced with challenges that are equally tremendous, including nonprofits struggling with resource insufficiency. While the private for-profit and public sectors have clear and strong institutional identities, the same is not necessarily true for the nonprofit sector, which still has to establish its institutional autonomy and independence to secure, inter alia, its financial stability and sustainability (Valentinov and Vaceková 2015; Svidroňová 2013). Much of the work that needs to be done toward this goal involves the scientific analysis and reconstruction of the policy framework of the Czech nonprofit sector. The available "standard" funding sources should be critically reviewed with regard to their applicability in the changing (post-) transitional context. Further empirical work is required for clarifying the factual basis of alternative funding sources and 
for understanding the crowdfunding phenomenon. These are the tasks to which the follow-up research will turn.

The obtained results suggest policy implications for two subjects on the crowdfunding market. First, intermediates (crowdfunding platforms) should consider ways to help fund seekers set up realistic projects and financial goals to raise funds or to be overfunded. With a higher rate of successful projects, the platform gains credibility and can attract additional fundraisers. One of the ways to do this could be to set up lower and upper limits for the financial goal. Secondly, the results imply a lower capability of NGOs raising extra funds. Although the exact reason that other project creators succeed more in this regard was not determined, it could be assumed that NGO projects are less attractive and/or offer less interesting rewards. Therefore, it is suggested that NGOs as project creators improve their marketing strategy and focus on making their project more engaging.

In order to propose policy recommendations connected with Czech nonprofits related to alternative funding sources, it is important to note that there is no unified legislative regulating process on raising funds through crowdfunding. Raising funds on a reward-based platform is not considered to be a public collection as it is in the case of donation-based crowdfunding; thus, the funds raised are subject to taxation. To support the NGOs in the process of finding additional sources, the framework of the process itself has to be re-considered as a tax-deduction possibility. Future studies based on qualitative research or a mixed-method approach should be conducted to determine the extent to which the resources gained this way are being used for publicly beneficial purposes.

All over the world, nonprofit organizations are experiencing the challenging implications of austerity and financial uncertainty and are turning to alternative funding sources to meet the emerging survival challenges. Scholars and practitioners broadly agree that this may be an essential coping strategy for those nonprofit organizations that are affected by cuts in public funding (Vaceková et al. 2017). Public-administration literature furthers this position by indicating the increasing involvement of nonprofit organizations in the public-private mix of social-service delivery (e.g. Pollitt and Bouckaert 2000; Žitek et al. 2016). Also, the current institutional and regulatory environment explicitly promotes nonprofit self-financing initiatives (cf. Vaceková et al. 2017). In the Czech Republic, it is primarily the government itself that expects funds outside public budgets to be raised to boost nonprofit autonomy. This political attitude is evidenced by the recent adoption of policies that counteract the legacy of the nanny state and foster independence. The new national policy toward nonprofit organizations for 2015-2020, as approved at the Czech government assembly on 29 July 2015, is similarly remarkable. Under these circumstances, it is only natural that nonprofit scholars have started a creative search for alternative funding sources and their justification, which could help to productively harness the nonprofit policy potential. 


\section{Conclusions}

The research on alternative nonprofit funding sources with a focus on crowdfunding led us to open a space in which to outline the need for further possible solutions and to emphasize the importance of developing scientific and societal attitudes or practices in the area of nonprofit-sector studies, even beyond the borders of conventional thinking regarding resource insufficiency. The paper focused on rewardbased crowdfunding and identified the factors affecting overfunding for campaigns launched on the Czech reward-based crowdfunding platform Hithit, specifically focusing on projects created by NGOs. Comparing the outcomes of the overall sample and NGO projects, most effects were found to be consistent. Across all the models, the funders were identified to have a positive effect on overfunding, whereas a higher requested amount negatively influences the collection of extra funds. Moreover, it was discovered that backers each contribute more when the requested amount is set at a higher level. This was, however, proven only for the overall sample. Certain characteristics of the projects were not proven to be significant across all samples: video, number of updates, and number of rewards. The estimations showed that overfunding is not favorable for projects created by NGOs. The estimation that focused solely on NGOs consistently found that the length of the organization's existence was insignificant when raising extra funds. The lessons learned clearly show the importance of the policy framework of the nonprofit environment in the (post-) transitional context of the Czech Republic. The paper outcomes could thus serve academics and nonprofit practitioners, but also provide a broad basis for a conceptual, organizational, and legislative redefinition of the Czech nonprofit sector. One of the key drivers of this ongoing regulatory policy process is the proliferation of new and alternative funding possibilities for NGOs, enabling them to achieve longterm sustainability, not only in fiscal terms.

\section{Acknowledgement}

This contribution was supported by the Grant Agency of Masaryk University in Brno, No. MUNI/A/1074/2016.

\section{References}

Agrawal, A. K., C. Catalini and A. Goldfarb. 2011. "The Geography of Crowdfunding" NBER Working Paper, No. 16820.

Anheier, H. K., L. Carlson and J. Kendall. 2001. Third Sector Policy at the Crossroads: Continuity and Change in the World of Nonprofit Organizations. London: Routledge. 
Belleflamme, P., T. Lambert and A. Schwienbacher. 2010. "Crowdfunding: An Industrial Organization Perspective." Prepared for the workshop Digital Business Models: Understanding Strategies, held in Paris on June.

Belleflamme, P., T. Lambert and A. Schwienbacher. 2013. "Individual Crowdfunding Practices." Venture Capital 15(4), 313-333.

Belleflamme, P., Lambert, T., \& Schwienbacher, A. 2014. "Crowdfunding: Tapping the right crowd." Journal of business venturing 29(5), 585-609.

Belleflamme, P., N. Omrani and M. Peitz. 2016. "Understanding the Strategies of Crowdfunding Platforms." DICE Report 14(2), 6.

Billis, D. and H. Glennerster. 1998. "Human Services and the Voluntary Sector: Towards a Theory of Comparative Advantage." Journal of Social Policy 27(01), 79-98.

Bode, I. and T. Brandsen. 2014. "State-Third Sector Partnerships: A Short Overview of Key Issues in the Debate." Public Management Review 16(8), 1055-1066.

Cameron, A. C. and P. K. Trivedi. 2005. Microeconometrics: Methods and Applications. New York: Cambridge University Press.

Casey, J. 2015. The Nonprofit World: Civil Society and the Rise of the Nonprofit Sector. London: Lynne Rienner Publishers.

Casey, J. 2016. "Comparing Nonprofit Sectors Around the World: What Do We Know and How Do We Know It?" The Journal of Nonprofit Education and Leadership 6(3), 187-223.

Castrataro, D. 2011. "A Social History of Crowdfunding." Available at https://socialmediaweek.org/blog/2011/12/a-social-history-of-crowdfunding/ (last accessed 15 September 2017).

CIVICUS. 2013. The CIVICUS 2013 Enabling Environment Index. Johannesburg, South Africa: Publisher: CIVICUS. Available at http://civicus.org/images/Civicus_EEI\%20REPORT\%202013_WEB_FINAL.pdf (last accessed 20. 8.2017).

Colás, A. 2002. "The Class Politics of Globalisation.” In M. Rupert and H. Smith (eds) Historical Materialism and Globalisation. London and New York: Routledge. 191-210.

Cordova, A., J. Dolci and G. Gianfrate. 2015. “The Determinants of Crowdfunding Success: Evidence from Technology Projects." Procedia-Social and Behavioral Sciences 181, 115-124.

DiMaggio, P. J. and H. K. Anheier. 1990. "The Sociology of Nonprofit Organizations and Sectors." Annual Review of Sociology 16(1), 137-159. 
Fowler, F. J. 1995. Improving Survey Questions: Design and Evaluation. Thousand Oaks, California: SAGE Publications.

Giudici, G., M. Guerini and C. Rossi Lamastra. 2013. Why Crowdfunding Projects can Succeed: The Role of Proponents' Individual and Territorial Social Capital. (April 24, 2013). Available at SSRN: https://ssrn.com/abstract=2255944 or http://dx.doi.org/10.2139/ssrn.2255944

Grønbjerg, K. A. 1994. "Using NTEE to Classify Non-Profit Organisations: An Assessment of Human Service and Regional Applications." VOLUNTAS: International Journal of Voluntary and Nonprofit Organizations 5(3), 301-328.

Horák, P., M. Horáková and T. Sirovátka. 2013. "Recent Trends and Changes in Czech Social Services in the European Context: the Case of Childcare and Elderly Care." Special English Issue 2013, 5-19.

Hosmer, D. W. and S. Lemeshow. 2005. "Multiple Logistic Regression.” Applied Logistic Regression 2, 31-46.

Hrůza, F. 2013. "Liquidity Management as a Space for Public Sector Innovation: How the Public Sector Approach to This Issue Has Developed through the Time until Now?"In ZHU Xiao-ning and ZHAO Shu-rong. PROCEEDINGS OF 2013 INTERNATIONAL CONFERENCE ON PUBLIC ADMINISTRATION $\left(9^{\text {th }}\right)$. Chengdu: University of Electronic Science and Technology of China Press (UESTC Press), 2013. s. 413-421, 9 s. ISBN 978-7-5647-1920-3.

Hrůza, F. and P. Valouch. 2014. "Innovation of Public Financial Management Practice Through New Accounting and Management Approach."In ZHU Xiaoning and ZHAO Shurong. PROCEEDINGS OF 2014 INTERNATIONAL CONFERENCE ON PUBLIC ADMINISTRATION $\left(10^{\text {th }}\right)$. Chengdu: University of Electronic Science and Technology of China Press (UESTC Press), 2014. s. 621-628, 8 s. ISBN 978-7-5647-2652-2.

James, E. (ed.). 1989. The Nonprofit Sector in International Perspective: Studies in Comparative Culture and Policy. New York: Oxford University Press.

Joenssen, D. W., A. Michaelis and T. Müllerleile. 2014. A Link to New Product Preannouncement: Success Factors in Crowdfunding. (August 6, 2014). Available at SRN: https://ssrn.com/abstract $=2476841$

Kleemann, F., G. G. Voß and K. Rieder. 2008. "Un(der) Paid Innovators: The Commercial Utilization of Consumer Work through Crowdsourcing."Science, Technology \& Innovation Studies 4(1), 5-26.

Koch, J. A. and M. Siering. 2015. Crowdfunding Success Factors: The Characteristics of Successfully Funded Projects on Crowdfunding Platforms. (April 4, 2015). Proceedings of the $23^{\text {rd }}$ European Conference on Information Systems (ECIS 2015); Muenster, Germany 2015. Available at SSRN: https://ssrn.com/ abstract $=2808424$ 
Kramer, R. M. 1981. Voluntary Agencies in the Welfare State. California: University of California Press.

Kuppuswamy, V. and B. L. Bayus. 2013. "Crowdfunding Creative Ideas: The Dynamics of Project Backers in Kickstarter."UNC Kenan-Flagler Research Paper 2013-15.

Lewis, D. 1998. “Nongovernmental Organizations, Business, and the Management of Ambiguity." Nonprofit Management and Leadership 9(2), 135-152.

Liu, M. M. 2015. Angels without Borders: Trends and Policies Shaping Angel Investment Worldwide. Singapore: World Scientific Publishing Company.

McCarthy, K. D., V. A. Hodgkinson and R. D. Sumariwalla. 1992. The Nonprofit Sector in the Global Community: Voices from many Nations. San Francisco: Jossey-Bass.

Mollick, E. 2014. “The Dynamics of Crowdfunding: An Exploratory Study." Journal of Business Benturing 29(1), 1-16.

Morduch, J. 1999. “The Microfinance Promise." Journal of Economic Literature 37(4), 1569-1614.

Murray Svidroňová, M., G. Vaceková and V. Valentinov. 2016. “The Theories of Non-Profits: A Reality Check from Slovakia." Lex localis - Journal of Local Self-Government 14(3), 401-420.

Navrátil, J. and G. Vaceková. 2015. "Determinants of the Success of NGOs' Accession to EU Funds in the Czech Republic." In D. Špalková and L. Matějová (eds). Current Trends in Public Sector Research: Proceedings of the $19^{\text {th }}$ International Conference. Brno: Masarykova Univerzita, 402-408.

Nemec, J., M. Orviska and C. Lawson. 2016. "The Role of Accountability Arrangements in Social Innovations: Evidence from the UK and Slovakia.” NISPAcee Journal of Public Administration and Policy 9(1), 73-96.

Nemec, J., D. Špaček, P. Suwaj and A. Modrzejewski. 2014. "A. Public Management as a University Discipline in New European Union Member States." Public Management Review 14(8), 1087-1108.

Ordanini, A., L. Miceli, M. Pizzetti and A. Parasuraman. 2011. "Crowd-Funding: Transforming Customers into Investors through Innovative Service Platforms." Journal of Service Management 22(4), 443-470.

Ostrander, S. A. 1989. "Private Social Services: Obstacles to the Welfare State?" Nonprofit and Voluntary Sector Quarterly 18(1), 25-45.

Pollitt, C. and G. Bouckaert. 2000. "Public Management Reform: A Comparative Perspective." In Notes Form Supporting the International Conference on Modernization and State Reform. Vol. 13 Rio de Janeiro. 
Pryor, F. L. 2012. "Determinants of the Size of the Nonprofit Sector." The European Journal of Comparative Economics 9(3), 337-348.

Salamon, L. M. 1987. "Partners in Public Service: The Scope and Theory of Government-Nonprofit Relations." In W. W. Powell (ed.). The Nonprofit Sector: A Research Handbook. New Haven, CT, USA: Yale University Press, 99-117.

Salamon, L. M. 1994. “The Rise of the Nonprofit Sector." Foreign Affairs 73(4), $109-122$.

Salamon, L. M. 2010. "Putting the Civil Society Sector on the Economic Map of the World." Annals of Public and Cooperative Economics 81(2), 167-210.

Salamon, L. M. and H. K. Anheier. 1992. "In Search of the Non-Profit Sector. I: The Question of Definitions." VOLUNTAS: International Journal of Voluntary and Nonprofit Organizations 3(2), 125-151.

Salamon, L. M. and H. K. Anheier. 1997. Defining the Nonprofit Sector: A CrossNational Analysis. Manchester University Press.

Salamon, L. M. and H. K. Anheier. 1998. Nonprofit Institutions and the 1993 System of National Accounts. Baltimore: Johns Hopkins University Institute for Policy Studies.

Salamon, L. M., H. K. Anheier, R. List, S. Toepler and S. W. Sokolowski. 1999. Global Civil Society: Dimensions of the Nonprofit Sector. Baltimore: The Johns Hopkins Center for Civil Society Studies.

Salamon, L. M. and S. W. Sokolowski. 2010. Global Civil Society: Dimensions of the Nonprofit Sector. $3^{\text {rd }}$ edn. Bloomfield, VT: Kumarian.

Salamon, L. M. and S. W. Sokolowski. 2016a. “The Size and Scope of the European Third Sector." Working Paper 13/2016. Available at http://thirdsectorimpact (last accessed 17 September 2017).

Salamon, L. M., S. W. Sokolowski and H. K. Anheier. 2000. Social Origins of Civil Society: An Overview. Baltimore: Johns Hopkins Center for Civil Society Studies.

Skocpol, T. 2011. “Civil Society in the United States." In M. Edwards (ed.). The Oxford Handbook of Civil Society. Oxford: Oxford University Press, 109-121.

Soukopová, J. and D. Klimovský. 2016. "Local Governments and Local Waste Management in the Czech Republic: Producers or Providers?” NISPAcee Journal of Public Administration and Policy 9(2), 217-237.

Svidroňová, M. 2013. "Sustainability Strategy of Non-Government Organisations in Slovakia." E+M Ekonomie a management 16(3), 85-100. 
Vaceková, G., V. Valentinov and J. Nemec. 2017. "Rethinking Nonprofit Commercialization: The Case of the Czech Republic." VOLUNTAS: International Journal of Voluntary and Nonprofit Organizations 28 (5), 1-21.

Valentinov, V. 2011. "The Meaning of Nonprofit Organization: Insights from Classical Institutionalism." Journal of Economic Issues 45(4), 901-916.

Valentinov, V., S. Hielscher and I. Pies. 2015. "Nonprofit Organizations, Institutional Economics, and Systems Thinking."Economic Systems 39(3), 491-501.

Valentinov, V. and G. Vaceková. 2015. "Sustainability of Rural Nonprofit Organizations: Czech Republic and beyond." Sustainability 7(8), 9890-9906.

Younkin, P. and K. Kashkooli. 2016. "What Problems does Crowdfunding Solve?" California Management Review 58(2), 20-43.

Zvilichovsky, D., Y. Inbar and O. Barzilay. 2015. Playing both Sides of the Market: Success and Reciprocity on Crowdfunding Platforms. (September 17, 2015). Available at SSRN: https://ssrn.com/abstract $=2304101$ or http://dx.doi. org/10.2139/ssrn.2304101

Žítek V., V. Klímová and M. Králová. 2016. “Assessment of Regional Innovation Systems as an Assumption for Innovation Policy Adjustment." Transylvanian Review of Administrative Sciences 2016(49E), 169-186. 


\section{Appendix 1 Correlation matrix}

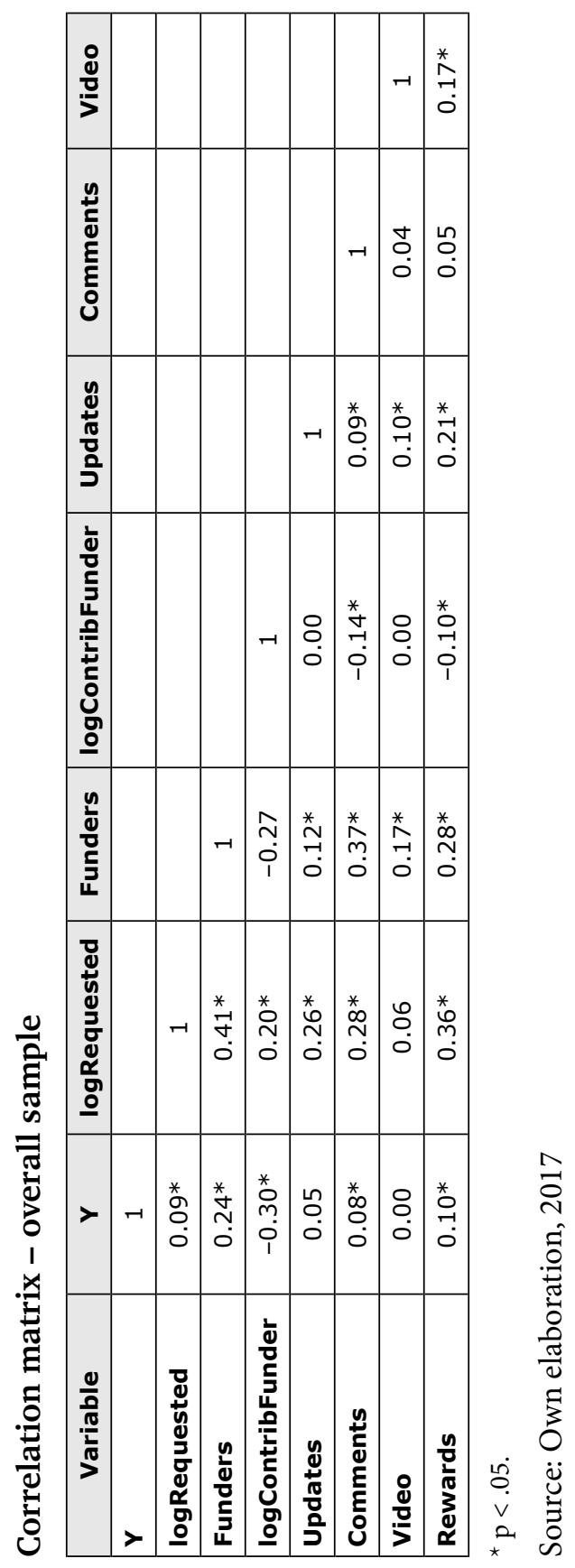




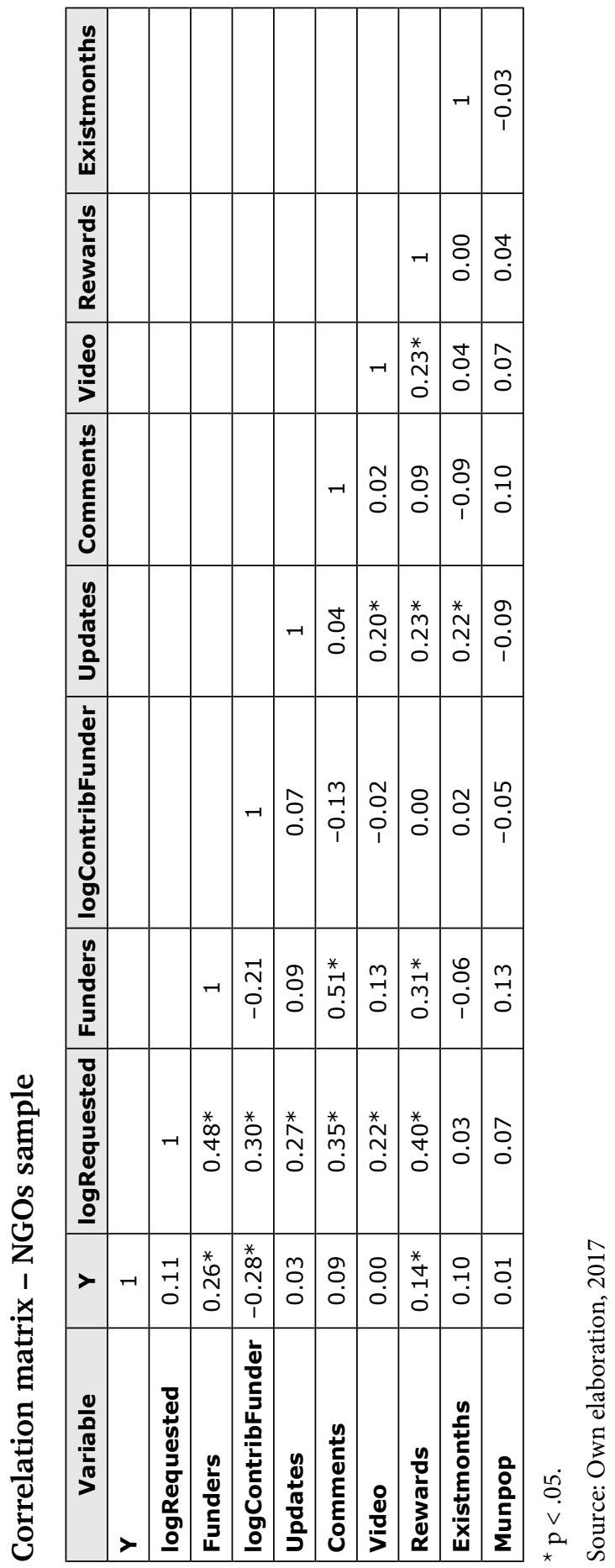




\section{Appendix 2 Descriptive statistics}

\begin{tabular}{|c|c|c|c|c|c|c|c|c|c|c|c|c|}
\hline \multirow{4}{*}{$\begin{array}{l}0 \\
\text { 언 }\end{array}$} & $\underset{\Sigma}{\stackrel{x}{\pi}}$ & $\underset{⿱}{\tilde{m}}$ & $\mid \begin{array}{l}8 \\
0 \\
0 \\
8 \\
0 \\
0 \\
8 \\
0 \\
i\end{array}$ & 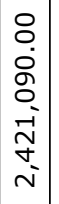 & $\begin{array}{l}8 \\
0 \\
0 \\
m \\
-1 \\
-1 \\
N\end{array}$ & $\begin{array}{l}m \\
\mathfrak{m} \\
\stackrel{N}{N} \\
\stackrel{\sigma}{\sigma}\end{array}$ & $\begin{array}{l}\circ \\
\circ \\
\stackrel{-}{1} \\
-1\end{array}$ & $\begin{array}{l}8 \\
\dot{0} \\
\text { மn }\end{array}$ & $\begin{array}{l}8 \\
\\
-i\end{array}$ & 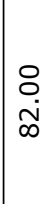 & 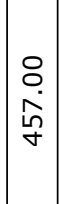 & 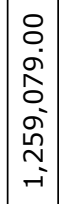 \\
\hline & $\frac{5}{\Sigma}$ & $\begin{array}{l}0 \\
0 \\
-i\end{array}$ & $\mid \begin{array}{l}8 \\
0 \\
8 \\
8 \\
0 \\
0 \\
-1\end{array}$ & $\begin{array}{l}0 \\
0 \\
0 \\
\stackrel{N}{1} \\
0 \\
0 \\
-1\end{array}$ & $\begin{array}{l}\text { ○ } \\
\stackrel{\text { n் }}{N}\end{array}$ & $\begin{array}{l}J \\
\infty \\
\infty \\
\infty \\
\stackrel{0}{\sim}\end{array}$ & $\begin{array}{l}8 \\
0 \\
0\end{array}$ & $\begin{array}{l}0 \\
0 \\
0\end{array}$ & 8 & $\begin{array}{l}\circ \\
\dot{\sigma}\end{array}$ & $\begin{array}{c}m \\
\sim \\
- \\
0\end{array}$ & \begin{tabular}{l}
8 \\
0 \\
$\emptyset$ \\
\hdashline
\end{tabular} \\
\hline & $\begin{array}{l}\dot{\Xi} \\
\dot{0} \\
\dot{0} \\
\dot{n}\end{array}$ & $\mid \begin{array}{l} \\
\infty \\
\stackrel{0}{-} \\
0 \\
0\end{array}$ & $\left|\begin{array}{l}0 \\
0 \\
0 \\
\tilde{V} \\
0 \\
-1 \\
0 \\
-1\end{array}\right|$ & 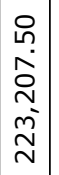 & $\begin{array}{l}-1 \\
\infty \\
\stackrel{\sim}{ } \\
\sim \\
\sim\end{array}$ & $\begin{array}{l}0 \\
\infty \\
\hat{1} \\
\hat{0} \\
0\end{array}$ & $\left|\begin{array}{l}0 \\
0 \\
m\end{array}\right|$ & $\begin{array}{l}\infty \\
\infty \\
\dot{\sigma}\end{array}$ & $\vec{m}$ & $\begin{array}{l}\tilde{\sigma} \\
0 \\
0 \\
-1\end{array}$ & $\begin{array}{l}\hat{\infty} \\
\infty \\
\dot{\sigma} \\
\sigma\end{array}$ & 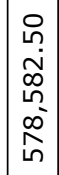 \\
\hline & $\begin{array}{l}\frac{5}{0} \\
\frac{d}{\Sigma}\end{array}$ & 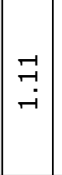 & $\left|\begin{array}{l}0 \\
0 \\
-1 \\
\sigma \\
\sigma \\
\hat{N} \\
\end{array}\right|$ & 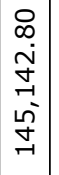 & $\begin{array}{l}-1 \\
0 \\
0 \\
0 \\
-1\end{array}$ & 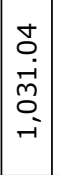 & $\mid \begin{array}{l}g \\
\dot{v} \\
\dot{m}\end{array}$ & กْ & ᄋి & $\mid \begin{array}{l}\alpha \\
\sigma \\
\omega \\
\sigma\end{array}$ & $\begin{array}{c}\hat{\emptyset} \\
\stackrel{1}{\sigma} \\
ન \\
-\end{array}$ & 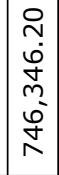 \\
\hline \multirow{4}{*}{ 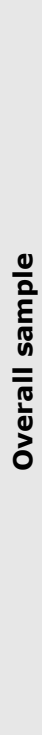 } & $\begin{array}{l}\underset{x}{\mathbb{\pi}} \\
\sum\end{array}$ & \begin{tabular}{|c|} 
\\
\\
$\tilde{\sigma}$ \\
0 \\
0
\end{tabular} & $\mid \begin{array}{l}8 \\
0 \\
0 \\
8 \\
0 \\
0 \\
8 \\
0 \\
i\end{array}$ & 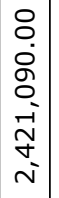 & 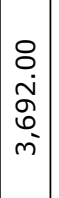 & $\begin{array}{c}0 \\
1 \\
\sim \\
N \\
\infty \\
-1 \\
\infty\end{array}$ & 号 & $\begin{array}{l}8 \\
\text { бં }\end{array}$ & $\begin{array}{l}8 \\
\text { - } \\
-1\end{array}$ & $\begin{array}{l}8 \\
\text { ․ } \\
\text { N }\end{array}$ & & \\
\hline & $\frac{\Sigma}{\Sigma}$ & $\begin{array}{l}\circ \\
\stackrel{\circ}{-} \\
-i\end{array}$ & $\mid$\begin{tabular}{l|}
8 \\
0 \\
8 \\
8 \\
0 \\
0 \\
-1
\end{tabular} & $\begin{array}{l}0 \\
0 \\
0 \\
\stackrel{N}{1} \\
0 \\
0 \\
-1\end{array}$ & $\begin{array}{l}8 \\
\stackrel{8}{1} \\
\end{array}$ & $\left|\begin{array}{c}+ \\
\infty \\
\infty \\
\infty \\
\stackrel{+}{\sim}\end{array}\right|$ & $\begin{array}{l}0 \\
0 \\
0\end{array}$ & $\begin{array}{l}8 \\
0 \\
0\end{array}$ & $\begin{array}{l}8 \\
0 \\
0\end{array}$ & $\begin{array}{l}\circ \\
\dot{\sigma}\end{array}$ & & \\
\hline & 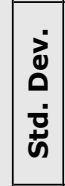 & $\begin{array}{l} \\
\stackrel{n}{m} \\
0 \\
0\end{array}$ & 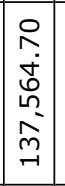 & $\begin{array}{c}0 \\
m \\
0 \\
+ \\
0 \\
n \\
\\
-1\end{array}$ & 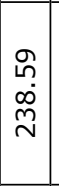 & $\begin{array}{l}-1 \\
0 \\
\dot{0} \\
0\end{array}$ & $\mid \begin{array}{l}0 \\
-1 \\
\dot{\sigma}\end{array}$ & $\begin{array}{l}\hat{\alpha} \\
\dot{0}\end{array}$ & $\stackrel{m}{m}$ & $\begin{array}{l}\infty \\
\stackrel{\infty}{1} \\
\infty\end{array}$ & & \\
\hline & $\begin{array}{l}\Sigma \\
\frac{5}{0} \\
\Sigma \\
\Sigma\end{array}$ & 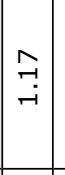 & 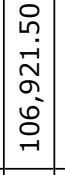 & $\mid \begin{array}{c}0 \\
0 \\
0 \\
0 \\
\tilde{m} \\
\\
\cong \\
-1\end{array}$ & $\begin{array}{l}\stackrel{\vartheta}{\sim} \\
\infty \\
\stackrel{n}{n} \\
\sim\end{array}$ & $\begin{array}{c}0 \\
0 \\
-1 \\
0 \\
-1 \\
0 \\
-1\end{array} \mid$ & $\begin{array}{l}\hat{n} \\
\text { m }\end{array}$ & $\stackrel{m}{0}$ & $\begin{array}{l}\hat{\infty} \\
0 \\
0\end{array}$ & 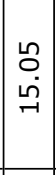 & & \\
\hline & $\frac{\frac{0}{0}}{\frac{\pi}{\pi}}$ & 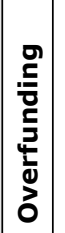 & 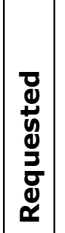 & 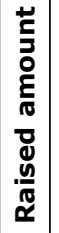 & 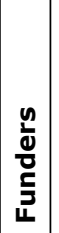 & 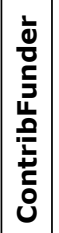 & 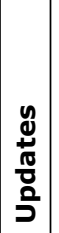 & 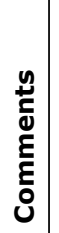 & : & 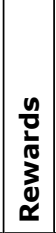 & 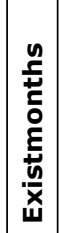 & 高 \\
\hline
\end{tabular}




\section{Appendix 3 Binary logistic regression outcome}

\begin{tabular}{|c|c|c|c|}
\hline \multirow[t]{2}{*}{ Variables } & \multirow{2}{*}{$\begin{array}{c}\text { Overall } \\
\text { Model } 1\end{array}$} & \multicolumn{2}{|c|}{ NGO } \\
\hline & & Model 2 & Model 3 \\
\hline Funders & $1.04 * * *$ & $1.03 * * *$ & $1.03 * * *$ \\
\hline logRequested & $6.23 \mathrm{e}^{-14 * * *}$ & $3.31 \mathrm{e}^{-06}$ & $8.1 \mathrm{e}^{-04 * * *}$ \\
\hline logContribFunder & $1.13 \mathrm{e}^{-13 * * *}$ & 0.02 & $46.08^{*}$ \\
\hline logRequested* logContribFunder & $1172.63 * * *$ & 5.40 & \\
\hline Updates & 1.02 & 1.00 & 1.00 \\
\hline Comments & $0.96 * *$ & 0.98 & 0.97 \\
\hline Video & 0.83 & 0.53 & 0.53 \\
\hline Rewards & 0.99 & 1.01 & 1.01 \\
\hline NGOnotNGO & $0.63 *$ & & \\
\hline Existmonths & & 1.00 & 1.00 \\
\hline Munpop & & 0.99 & 1.00 \\
\hline Arts & 1.13 & 0.87 & 0.89 \\
\hline Community & 1.08 & & \\
\hline Design_Technology & 0.80 & 0.54 & 0.55 \\
\hline Education & $2.73 * * *$ & $6.03 * * *$ & $5.93 * * *$ \\
\hline Literature_Photo & $0.55^{* *}$ & 0.91 & 0.90 \\
\hline Movie & 1.54 & 1.69 & 1.71 \\
\hline Music & & 1.21 & 1.17 \\
\hline Others & 0.95 & 0.20 & 0.19 \\
\hline Sport & 1.01 & 1.30 & 1.27 \\
\hline Theatre_Dance & 1.02 & 0.96 & 0.99 \\
\hline Constant & $7.7 \mathrm{e}^{+56 * * *}$ & $1.73 \mathrm{e}^{+20}$ & $8.1 \mathrm{e}^{+08 * * *}$ \\
\hline Observations & 612 & 212 & 212 \\
\hline Chi2 & 190.49 & 69.62 & 69.39 \\
\hline P-value & 0.00 & 0.00 & 0.00 \\
\hline Pseudo R2 & 0.23 & 0.24 & 0.24 \\
\hline
\end{tabular}

${ }^{* * *} \mathrm{p}<0.01,{ }^{* *} \mathrm{p}<0.05,{ }^{*} \mathrm{p}<0.1$

Source: Own elaboration, 2017 


\section{Appendix 4 Outcomes classification}

\begin{tabular}{|l|c|c|c|c|c|}
\hline \multirow{2}{*}{ Sample } & \multirow{2}{*}{ Model } & \multicolumn{3}{|c|}{ Correctly classified } & \multirow{2}{*}{$\begin{array}{c}\text { Area under } \\
\text { ROC curve }\end{array}$} \\
\cline { 3 - 5 } & & Positive & Negative & Total & \\
\hline \multirow{2}{*}{ Overall sample } & Model 1 & $76.60 \%$ & $66.01 \%$ & $72.22 \%$ & $80.74 \%$ \\
\hline \multirow{2}{*}{ NGOs } & Model 2 & $72.17 \%$ & $76.29 \%$ & $74.06 \%$ & $81.80 \%$ \\
\cline { 2 - 5 } & Model 3 & $72.17 \%$ & $78.35 \%$ & $75.00 \%$ & $81.69 \%$ \\
\hline
\end{tabular}

Source: Own elaboration, 2017

Note: All models indicate almost the same ability to correctly categorize overfunded and funded projects, on average $74 \%$ of the whole sample. When models estimating only NGO projects are considered, the results show that more projects were correctly classified for both samples when the interaction term was excluded from the estimation. Another way to estimate how well the model is capable of predicting accurate results is to compute the receiver operating characteristics (ROC) curve. The curve plots the fraction of $y=1$ values correctly classified against the fraction of $y=0$ values incorrectly specified as the cut-off c varies (Cameron and Trivedi 2005). Similarly, all models obtained approximately the same results. The predicting capability is considered to be good when the value under the ROC curve reaches a level between 80 and $90 \%$. 